\title{
Microbacterium invictum sp. nov., isolated from homemade compost
}

\author{
Ivone Vaz-Moreira, ${ }^{1,2}$ Ana R. Lopes, ${ }^{2}$ Cátia Faria, ${ }^{2}$ Cathrin Spröer, $^{3}$ \\ Peter Schumann, ${ }^{3}$ Olga C. Nunes ${ }^{2}$ and Célia M. Manaia ${ }^{1}$ \\ ${ }^{1}$ Escola Superior de Biotecnologia, Universidade Católica Portuguesa, 4200-072 Porto, Portugal \\ ${ }^{2}$ LEPAE - Departamento de Engenharia Química, Faculdade de Engenharia, Universidade do Porto, \\ 4200-465 Porto, Portugal \\ ${ }^{3} \mathrm{DSMZ}$ - Deutsche Sammlung von Mikroorganismen und Zellkulturen GmbH, Inhoffenstraße 7B, \\ D-38124 Braunschweig, Germany
}

\begin{abstract}
Strain DC-200 ${ }^{\top}$ was isolated from homemade compost produced from kitchen refuse and characterized using a polyphasic approach. The isolate was a Gram-positive motile short rod, facultatively aerobic, catalase-positive and oxidase-negative, and was able to grow at $10-37{ }^{\circ} \mathrm{C}$, $\mathrm{pH}$ 6.0-9.5 and with up to $5 \%$ of $\mathrm{NaCl}$. The peptidoglycan was of the type $\mathrm{B} 1$ alpha and the muramic acid residues were glycolylated. The major fatty acids were anteiso- $\mathrm{C}_{15 \text { : } 0}$ and anteiso$\mathrm{C}_{17: 0}$. The predominant respiratory menaquinones were MK-11 and MK-12. The $\mathrm{G}+\mathrm{C}$ content of the genomic DNA was $70 \mathrm{~mol} \%$. Based on the analysis of the 16S rRNA gene sequence, the closest phylogenetic neighbours of strain $\mathrm{DC}-200^{\top}$ were Microbacterium lacus A5E-52 ${ }^{\top}$

(98.7\%) and Microbacterium aoyamense KV-492 ${ }^{\top}$ (98.2\%). The phenetic characterization of the isolate supports its inclusion within the genus Microbacterium; however, its distinctive phenotypic features and the results from the 16S rRNA gene sequence analysis and the DNA-DNA hybridization study suggest that the isolate represents a novel species. The name Microbacterium invictum sp. nov. is proposed. The type strain is DC- $200^{\top}\left(=\mathrm{DSM} 19600^{\top}=\mathrm{LMG} 24557^{\top}\right)$.
\end{abstract}

Home composting is an ancient process of recycling domestic and agricultural organic waste, which is a mixture of soft 'green' domestic residues such as vegetable leaves, fruit skins or potato peelings and dry 'brown' material such as dead leaves or dried grass. Decomposition is performed by several micro-organisms, namely fungi and bacteria, that are present in the raw materials and able to survive the environmental stresses and competitive phenomena that occur during composting (Epstein, 1997). This paper reports the characterization of a strain (designated DC$200^{\mathrm{T}}$ ) that was isolated from fully decomposed homemade compost. 16S rRNA gene sequence analysis and DNADNA hybridization results showed that the strain is a member of the genus Microbacterium but does not belong to any of the more than 50 species currently included in this genus (Euzéby, 2008).

Strain DC- $200^{\mathrm{T}}$ was isolated from homemade compost produced by thermal digestion of kitchen refuse in a wooden domestic composter $\left(1 \mathrm{~m}^{3}\right)$, where temperatures of about $50{ }^{\circ} \mathrm{C}$ are reached (Vaz-Moreira et al., 2008). The

Abbreviation: MALDI-TOF, matrix-assisted laser-desorption/ionization time-of-flight.

The GenBank/EMBL/DDBJ accession number for the 16S rRNA gene sequence of strain DC-200 ${ }^{\top}$ is $\mathrm{AM} 949677$. isolate was purified by subculturing on plate count agar (PCA; Pronadisa) containing $\left(1^{-1}\right): 5 \mathrm{~g}$ tryptone, $2.5 \mathrm{~g}$ yeast extract, $1 \mathrm{~g}$ glucose and $15 \mathrm{~g}$ agar. Cultures were incubated at $30{ }^{\circ} \mathrm{C}$ and cells were stored at $-80{ }^{\circ} \mathrm{C}$ in nutrient broth with $15 \%(\mathrm{v} / \mathrm{v})$ glycerol for preservation. Colony and cell morphological descriptions, Gram-stain reaction, cytochrome- $c$ oxidase and catalase tests and endospore and motility visualizations were based on the methodologies of Murray et al. (1994) and Smibert \& Krieg (1994). Unless otherwise stated, all biochemical and physiological tests were performed as described previously (Vaz-Moreira et al., 2007). Biochemical and nutritional tests were assayed using the API 20E, API 20NE, API $50 \mathrm{CH}$ and API ZYM systems (bioMérieux) following the manufacturer's instructions, and API $50 \mathrm{CH}$ was inoculated with the medium recommended to test acid production and with mineral medium B (Barreiros et al., 2003) supplemented with $4 \mathrm{mM}\left(\mathrm{NH}_{4}\right)_{2} \mathrm{SO}_{4}$ and $0.5 \%$ yeast extract. Antibiotic susceptibility was assayed as described by Ferreira da Silva et al. (2006).

The determination of the genomic DNA G $+\mathrm{C}$ content and the analysis of respiratory quinones were performed as described previously (Vaz-Moreira et al., 2007) using the methods of Mesbah et al. (1989) and Tindall (1989), respectively. The cellular fatty acid compositions of strains 
Table 1. Differential characteristics of strain $\mathrm{DC}-200^{\top}$ and the type strains of closely related Microbacterium species

Strains: 1, Microbacterium invictum sp. nov. DC-200 ${ }^{\mathrm{T}} ; 2$, M. lacus DSM $18910^{\mathrm{T}} ; 3$, M. aoyamense DSM $19461^{\mathrm{T}}$. Data from this study. +, Positive; -, negative; w, weak; ND, no data available.

\begin{tabular}{|c|c|c|c|}
\hline Characteristic & 1 & 2 & 3 \\
\hline Isolation source & Homemade compost & Estuarine sediment & Soil \\
\hline Colony colour & White/yellow & Pale yellow & Pale yellow \\
\hline Motility & + & $-*$ & $-*$ \\
\hline \multicolumn{4}{|l|}{ Growth conditions } \\
\hline $\mathrm{pH}$ range & $6-9.5$ & $6-11^{*}$ & $5-11^{*}$ \\
\hline $5 \% \mathrm{NaCl}$ & + & $-^{*}$ & $+^{*}$ \\
\hline Anaerobic & + & - & ND \\
\hline Nitrate reduction & + & - & + \\
\hline Voges-Proskauer & + & - & - \\
\hline \multicolumn{4}{|l|}{ Oxidation (API 20E) } \\
\hline Amygdalin & + & - & + \\
\hline D-Glucose & + & - & + \\
\hline D-Mannitol & + & - & $\mathrm{w}$ \\
\hline L-Rhamnose & + & - & + \\
\hline D-Sorbitol & + & - & - \\
\hline Glucose fermentation & $\mathrm{W}$ & - & - \\
\hline \multicolumn{4}{|l|}{ Assimilation of: } \\
\hline$N$-Acetylglucosamine & + & - & + \\
\hline D-Fructose & + & - & + \\
\hline D-Galactose & - & - & + \\
\hline Potassium gluconate & + & - & + \\
\hline Glycogen & - & + & + \\
\hline Malate & - & - & + \\
\hline D-Mannitol & + & - & + \\
\hline Melezitose & - & + & - \\
\hline Raffinose & - & + & + \\
\hline L-Rhamnose & + & - & + \\
\hline D-Sorbitol & + & - & - \\
\hline Starch & - & $\mathrm{w}$ & + \\
\hline Sucrose & - & + & + \\
\hline Trehalose & - & + & + \\
\hline \multicolumn{4}{|l|}{ Enzymic activity } \\
\hline Alkaline phosphatase & + & - & - \\
\hline Cystine arylamidase & - & + & - \\
\hline Trypsin & - & + & - \\
\hline$\alpha$-Chymotrypsin & - & + & - \\
\hline$\alpha$-Galactosidase & - & + & - \\
\hline$\beta$-Galactosidase & + & - & + \\
\hline$\beta$-Glucuronidase & + & - & - \\
\hline Diamino acid in cell wall & Lys & Orn & $\operatorname{Orn}^{\star}$ \\
\hline Predominant menaquinones & MK-11, MK-12 & MK-12, MK-13* & MK-12, MK-13, MK-14* \\
\hline DNA G $+\mathrm{C}$ content $(\mathrm{mol} \%)$ & 70 & $69^{*}$ & $69^{\star}$ \\
\hline
\end{tabular}

${ }^{\star}$ Data from Kageyama et al. $(2006,2007)$.

cultivated on tryptic soy broth agar at $28{ }^{\circ} \mathrm{C}$ for 2 days were analysed as described by Kämpfer \& Kroppenstedt (1996). Purified peptidoglycan preparations were obtained after disruption of cells by shaking with glass beads and subsequent trypsin digestion, according to the method of Schleifer \& Seidl (1985). The amino-acid composition of the peptidoglycan hydrolysate $\left(4 \mathrm{M} \mathrm{HCl}, 100{ }^{\circ} \mathrm{C}, 16 \mathrm{~h}\right)$ was determined by using one-dimensional TLC on cellulose plates (Merck) using the solvent system of Rhuland et al. (1955) and gas chromatography of amino acids as described by Schumann et al. (1997) after derivatization according to MacKenzie (1987). Glycolyl residues were detected in the peptidoglycan with the method of Uchida et al. (1999). 
The nucleotide sequence of the 16S rRNA gene of strain DC- $200^{\mathrm{T}}$ was determined after PCR amplification of total DNA extracts as described by Ferreira da Silva et al. (2007). The 16S rRNA gene sequence was compared with others available in the GenBank/EMBL/DDBJ database using the FASTA package from EMBL-EBI. The phylogenetic analysis was conducted using MEGA version 3.1 (Kumar et al., 2004). Sequence alignment was performed with CLUSTAL $\mathrm{w}$ version 1.6 (Thompson et al., 1994). A total of 1377 nucleotide positions were included in the analysis. Non-homologous and ambiguous nucleotide positions were excluded from the calculations. Evolutionary distances were calculated using the model of Jukes \& Cantor (1969) and phylogenetic trees were constructed using neighbour-joining, maximum-parsimony and minimum-evolution methods to assess the stability. For DNA-DNA hybridization experiments, DNA was isolated using a French pressure cell (Thermo Spectronic) and purified by chromatography on hydroxyapatite as described by Cashion et al. (1977). DNA-DNA hybridizations were carried out as described by De Ley et al. (1970), under consideration of the modifications described by Huß et al. (1983), using a Cary 100 Bio UV/VIS spectrophotometer equipped with a Peltierthermostatted $6 \times 6$ multicell changer and a temperature controller with an in situ temperature probe (Varian). The analysis using matrix-assisted laser-desorption/ionization time-of-flight (MALDI-TOF) mass spectrometry of strain DC- $200^{\mathrm{T}}$ and close phylogenetic relatives was performed according to the method described by Tóth et al. (2008).

After $48 \mathrm{~h}$ incubation at $30{ }^{\circ} \mathrm{C}$, strain $\mathrm{DC}-200^{\mathrm{T}}$ formed white and convex colonies that were difficult to remove from the agar. Colonies acquired a yellow colour and smoother texture after 4-6 days. The results of the phenotypic characterization of strain DC- $200^{\mathrm{T}}$ are summarized in Table 1. The diamino acid of the peptidoglycan was lysine. Glycine, alanine and glutamic acid, but not homoserine or hydroxyglutamic acid, were detected in the peptidoglycan with the acyl type $N$-glycolyl. The fatty acid profile of strain DC- $200^{\mathrm{T}}$ contained mainly (>95\%) branched fatty acids and differed from those of its closest relatives, Microbacterium lacus DSM $18910^{\mathrm{T}}$ and Microbacterium aoyamense DSM $19461^{\mathrm{T}}$, by having a remarkably lower content of $\mathrm{C}_{16: 0}$ (Table 2). The predominant respiratory menaquinones were MK-11 and MK-12, with relative percentages of about $40 \%$. The minor components MK-9, MK-10 and MK-13 each represented less than $6 \%$ of the total. The $\mathrm{G}+\mathrm{C}$ content of the genomic DNA of strain DC- $200^{\mathrm{T}}$ was $70.1 \pm 0.3 \mathrm{~mol} \%$.

The above characteristics support the inclusion of strain DC- $200^{\mathrm{T}}$ in the genus Microbacterium, which is also supported by the $16 \mathrm{~S}$ rRNA gene sequence similarity values between this strain and $M$. lacus $\mathrm{A} 5 \mathrm{E}-52^{\mathrm{T}}(98.7 \%)$ and $M$. aoyamense KV-492 ${ }^{\mathrm{T}}$ (98.2 \%) (Fig. 1). However, the DNADNA hybridization analysis showed that, when the recommendations of a threshold value of $70 \%$ DNA-DNA relatedness for the definition of bacterial species (Wayne et al., 1987) are considered, strain DC- $200^{\mathrm{T}}$, M. lacus DSM
Table 2. Fatty acid profiles of strain $D C-200^{\top}$ and the type strains of closely related Microbacterium species after cultivation on tryptic soy broth agar for 2 days at $28^{\circ} \mathrm{C}$

Strains: 1, Microbacterium invictum sp. nov. DC- $200^{\mathrm{T}} ; 2$, M. lacus DSM $18910^{\mathrm{T}}$; 3, M. aoyamense DSM $19461^{\mathrm{T}}$. Data from this study. -, Not detected.

\begin{tabular}{|lccc|}
\hline Fatty acid (\%) & $\mathbf{1}$ & $\mathbf{2}$ & $\mathbf{3}$ \\
\hline Saturated & & & \\
$\mathrm{C}_{14: 0}$ & - & - & 1.1 \\
$\mathrm{C}_{15: 0}$ & - & 0.4 & 0.9 \\
$\mathrm{C}_{16: 0}$ & 3.5 & 18.6 & 21.9 \\
$\mathrm{C}_{17: 0}$ & 0.3 & 0.4 & - \\
$\mathrm{C}_{18: 0}$ & 0.3 & - & - \\
Branched & & & \\
iso- $\mathrm{C}_{14: 0}$ & 0.3 & 0.3 & 2.5 \\
iso- $\mathrm{C}_{15: 0}$ & 5.5 & 6.2 & 4.1 \\
anteiso- $\mathrm{C}_{15: 0}$ & 52.0 & 30.6 & 33.9 \\
iso- $\mathrm{C}_{16: 0}$ & 9.7 & 8.4 & 21.2 \\
iso- $\mathrm{C}_{17: 0}$ & 3.0 & 5.6 & 1.3 \\
anteiso- $\mathrm{C}_{17: 0}$ & 25.1 & 28.2 & 12.4 \\
iso- $\mathrm{C}_{18: 0}$ & 0.2 & - & - \\
Branched and unsaturated & & & \\
anteiso- $\mathrm{C}_{15: 1}$ & 0.1 & - & - \\
anteiso- $\mathrm{C}_{17: 1}$ & - & 1.3 & - \\
Hydroxylated & & & \\
3-OH $\mathrm{C}_{15: 0}$ & - & - & 0.7 \\
\hline
\end{tabular}

$18910^{\mathrm{T}}$ and M. aoyamense DSM $19461^{\mathrm{T}}$ represent three distinct species. The levels of DNA-DNA relatedness between strain DC-200 ${ }^{\mathrm{T}}$ and M. lacus DSM $18910^{\mathrm{T}}$ and $M$. aoyamense DSM $19461^{\mathrm{T}}$ were, respectively, 5.3 and $17.1 \%$. M. lacus DSM $18910^{\mathrm{T}}$ and M. aoyamense DSM $19461^{\mathrm{T}}$ exhibited $5 \%$ DNA-DNA relatedness between them. These results are in agreement with the correlation analysis that has demonstrated that strains with less than $98.7 \% 16 \mathrm{~S}$ rRNA gene sequence similarity present DNA-DNA reassociation values of less than $70 \%$ (Stackebrandt \& Ebers, 2006).

Strain DC- $200^{\mathrm{T}}$ could be distinguished from its closest neighbours M. lacus DSM $18910^{\mathrm{T}}$ and M. aoyamense DSM $19461^{\mathrm{T}}$ at the phenotypic and chemotaxonomic levels (Tables 1 and 2) by its ability to assimilate D-sorbitol but not raffinose, sucrose or trehalose, to ferment glucose and to produce alkaline phosphatase and $\beta$-glucuronidase, by the presence of lysine as the cell-wall diamino acid and MK-11 as a predominant menaquinone and by the higher relative percentage of anteiso- $\mathrm{C}_{15: 0}$ and the lower relative percentage of $C_{16: 0}$. Furthermore, strain DC- $200^{\mathrm{T}}$ could be differentiated from the type strains of Microbacterium species that show high 16S rRNA gene sequence similarities (Fig. 1) on the basis of MALDI-TOF mass spectra (Fig. 2). However, the similarity of mass spectra does not reflect the binary $16 \mathrm{~S}$ rRNA gene sequence similarity values of strain DC-200 ${ }^{\mathrm{T}}$ with its closest phylogenetic neighbours: for example, Microbacterium schleiferi DSM $20489^{\mathrm{T}}$ (NBRC 


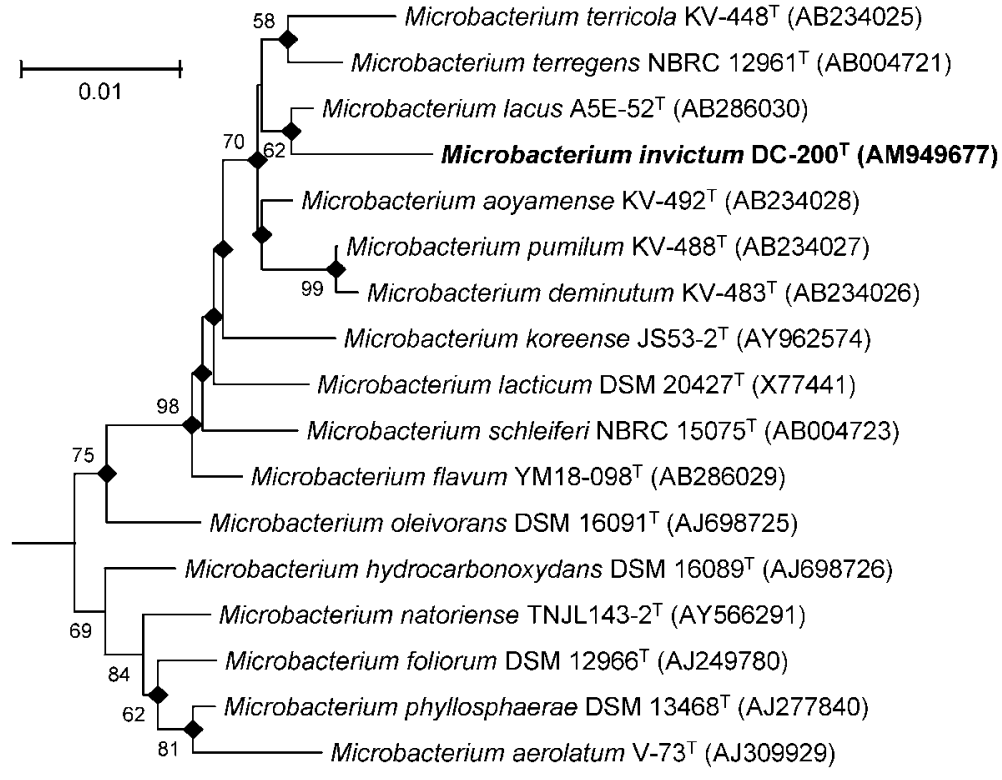

Fig. 1. Neighbour-joining tree based on $16 \mathrm{~S}$ rRNA gene sequences showing the phylogenetic relationship between strain $\mathrm{DC}-200^{\top}$ and other closely related species of the genus Microbacterium. Bootstrap values ( $>60 \%$ ) based on 10000 resamplings are shown at branch nodes. Filled diamonds indicate nodes that were also recovered with the maximumparsimony method. Bar, 0.01 substitutions per nucleotide position.
$15075^{\mathrm{T}} ; 97.6 \% 16 \mathrm{~S}$ rRNA gene sequence similarity to strain DC- $200^{\mathrm{T}}$ ) shows the most similar mass spectrum whereas M. lacus DSM $18910^{\mathrm{T}}$ and M. aoyamense DSM $19461^{\mathrm{T}}$, with the highest 16S rRNA gene sequence similarities (98.7 and $98.2 \%$, respectively), fall in a distant cluster. These distinctive features in combination with the DNA-DNA hybridization data support the proposal of a novel species, represented by strain $\mathrm{DC}-200^{\mathrm{T}}$, for which the name Microbacterium invictum sp. nov. is proposed.

\section{Description of Microbacterium invictum sp. nov.}

Microbacterium invictum (in.vic'tum. L. neut. adj. invictum invincible, powerful, that survives composting, also

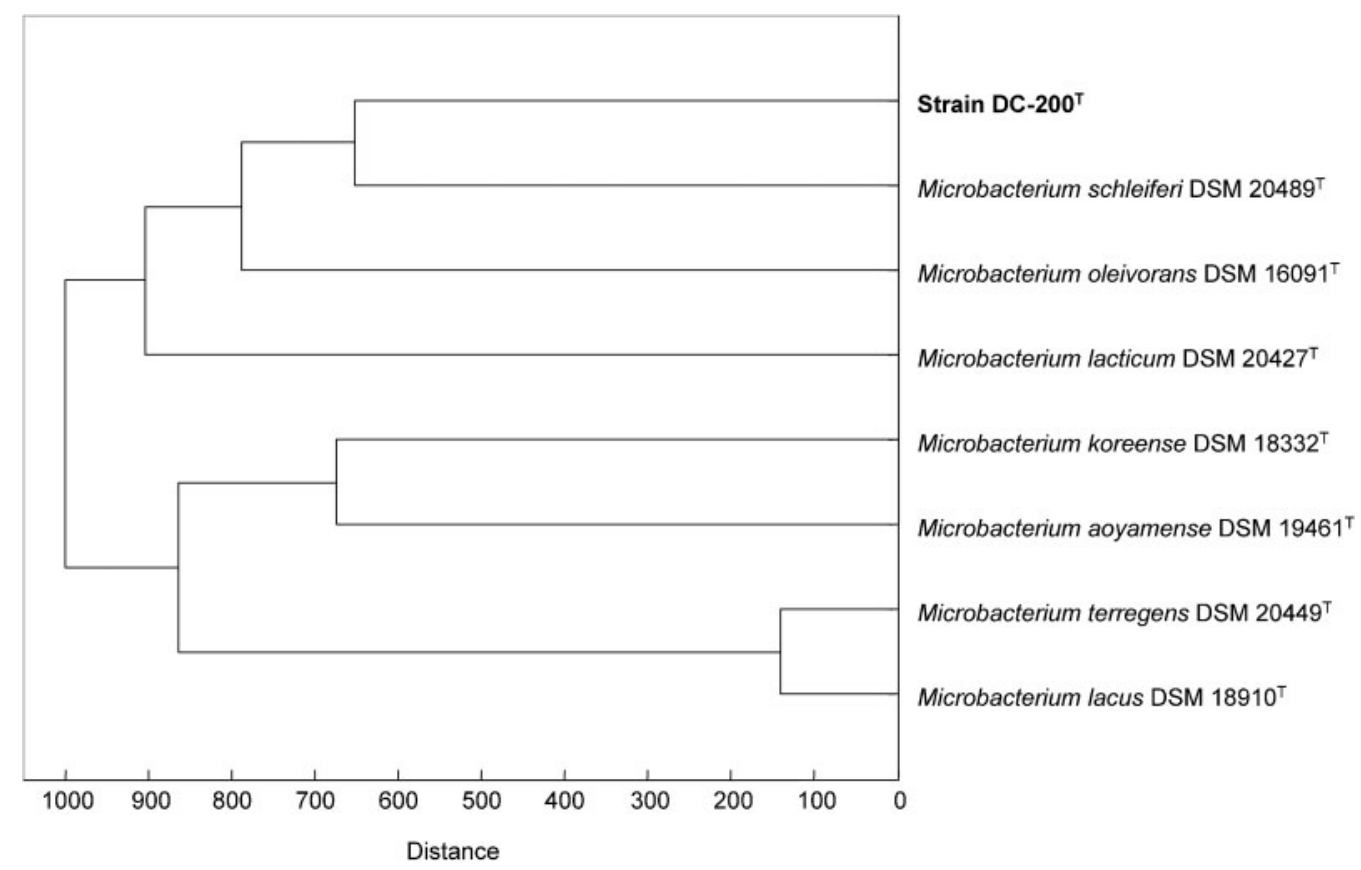

Fig. 2. Score-oriented dendrogram generated by BioTyper software (version 1.1; Bruker Daltonics) showing the similarity of MALDI-TOF mass spectra of cell extracts of strain $\mathrm{DC}-200^{\top}$, its closest relatives $M$. lacus DSM $18910^{\top}$ and $M$. aoyamense DSM $19461^{\top}$ as well as other related type strains of the genus Microbacterium. 
an ancient and popular designation attributed to Oporto city).

On PCA, colonies are white after 2 days of incubation and yellow after 5 days. Cells are Gram-positive motile short rods $(0.74 \pm 0.07 \mu \mathrm{m}$ long and $0.54 \pm 0.08 \mu \mathrm{m}$ wide $)$ and do not form spores. Catalase-positive and oxidasenegative. Growth occurs at $10-37{ }^{\circ} \mathrm{C}, \mathrm{pH} 6.0-9.5$ and with up to $5 \% \mathrm{NaCl}$. Nitrate is reduced to nitrite. Citrate is not used and $\mathrm{H}_{2} \mathrm{~S}$ and indole are not produced. Anaerobic growth is observed in the presence of nitrate. Voges-Proskauer test is positive. Hydrolyses gelatin, aesculin, starch (weakly) and $\varepsilon$-poly-caprolactone (weakly). Oxidizes (API 20E) and assimilates L-arabinose, D-glucose, D-mannitol, L-rhamnose and D-sorbitol; additionally, assimilates $N$-acetylglucosamine, cellobiose, Dfructose, gentiobiose, potassium gluconate, potassium 2ketogluconate, maltose, D-mannose, turanose, xylitol (weakly) and D-xylose, but not phenyl acetate, D-adonitol, adipate, aesculin, amygdalin, D-arabinose, D- and Larabitol, caprate, citrate, dulcitol, erythritol, D- and Lfucose, D-galactose, potassium 5-ketogluconate, glycerol, glycogen, inositol, inulin, lactose, D-lyxose, malate, melezitose, melibiose, raffinose, D-ribose, salicin, L-sorbose, starch, sucrose, D-tagatose, trehalose, L-xylose, methyl $\alpha$-D-glucopyranoside, methyl $\alpha$-D-mannopyranoside or methyl $\beta$-D-xylopyranoside. Glucose fermentation is weak and slow. Acid is produced from $\mathrm{N}$-acetylglucosamine, amygdalin, L-arabinose, arbutin, cellobiose, Dfructose, D-glucose, D-mannitol, D-mannose, L-rhamnose and salicin, with weak reactions observed for D-galactose, D-sorbitol and D-xylose, but not from D-adonitol, Darabinose, D- and L-arabitol, dulcitol, erythritol, D- and Lfucose, gentiobiose, gluconate or 2- and 5-ketogluconate, glycerol, glycogen, inositol, inulin, lactose, D-lyxose, maltose, melezitose, melibiose, raffinose, D-ribose, Lsorbose, starch, sucrose, D-tagatose, trehalose, turanose, xylitol, L-xylose, methyl $\alpha$-D-glucopyranoside, methyl $\alpha$-Dmannopyranoside or methyl $\beta$-D-xylopyranoside. Produces alkaline phosphatase, esterase (C4), esterase lipase (C8), leucine arylamidase, valine arylamidase, acid phosphatase, naphthol-AS-BI-phosphohydrolase, $\beta$-galactosidase, $\beta$-glucuronidase, $\alpha$ - and $\beta$-glucosidase and $N$ acetyl $\beta$-glucosamidase, but not arginine dihydrolase, lysine and ornithine decarboxylase, urease, tryptophan deaminase, lipase (C14), cystine arylamidase, trypsin, $\alpha$ chymotrypsin, $\alpha$-galactosidase, $\alpha$-mannosidase or $\alpha$-fucosidase. Growth occurs in the presence of $\left(\mu \mathrm{g} \mathrm{l}^{-1}\right)$ sulfamethoxazole/trimethoprim (23.75/1.25), meropenem (10) and ceftazidime (30). Major fatty acids are anteiso$\mathrm{C}_{15: 0}$ and anteiso- $\mathrm{C}_{17: 0}$. The peptidoglycan is of the type B1 alpha, with lysine as the diamino acid, and muramic acid residues are glycolylated. The predominant menaquinones are MK-11 and MK-12, in similar proportions. The DNA G+C content of the type strain is $70.1 \pm 0.3 \mathrm{~mol} \%$.

The type strain, DC- $200^{\mathrm{T}}\left(=\mathrm{DSM} 19600^{\mathrm{T}}=\mathrm{LMG} 24557^{\mathrm{T}}\right)$, was isolated from homemade compost.

\section{References}

Barreiros, L., Nogales, B., Manaia, C. M., Ferreira, A. C. S., Pieper, D. H., Reis, M. A. \& Nunes, O. C. (2003). A novel pathway for mineralization of the thiocarbamate herbicide molinate by a defined bacterial mixed culture. Environ Microbiol 5, 944-953.

Cashion, P., Holder-Franklin, M. A., McCully, J. \& Franklin, M. (1977). A rapid method for base ratio determination of bacterial DNA. Anal Biochem 81, 461-466.

De Ley, J., Cattoir, H. \& Reynaerts, A. (1970). The quantitative measurement of DNA hybridization from renaturation rates. Eur $J$ Biochem 12, 133-142.

Epstein, E. (1997). The Science of Composting. Lancaster, PA: Technomic Publishing Co. Inc.

Euzéby, J. P. (2008). List of Prokaryotic Names with Standing in Nomenclature, http://www.bacterio.net, last full update 10 April 2008.

Ferreira da Silva, M., Tiago, I., Veríssimo, A., Boaventura, A. R., Nunes, O. C. \& Manaia, C. M. (2006). Antibiotic resistance of enterococci and related bacteria in an urban wastewater treatment plant. FEMS Microbiol Ecol 55, 322-329.

Ferreira da Silva, M., Vaz-Moreira, I., Gonzalez-Pajuelo, M., Nunes, O. C. \& Manaia, C. M. (2007). Antimicrobial resistance patterns in Enterobacteriaceae isolated from an urban wastewater treatment plant. FEMS Microbiol Ecol 60, 166-176.

Huß, V. A. R., Festl, H. \& Schleifer, K. H. (1983). Studies on the spectrophotometric determination of DNA hybridization from renaturation rates. Syst Appl Microbiol 4, 184-192.

Jukes, T. H. \& Cantor, C. R. (1969). Evolution of protein molecules. In Mammalian Protein Metabolism, vol. 3, pp. 21-132. Edited by H. N. Munro. New York: Academic Press.

Kageyama, A., Takahashi, Y. \& Ōmura, S. (2006). Microbacterium deminutum sp. nov., Microbacterium pumilum sp. nov. and Microbacterium aoyamense sp. nov. Int J Syst Evol Microbiol 56, 2113-2117.

Kageyama, A., Takahashi, Y., Matsuo, Y., Adachi, K., Kasai, H., Shizuri, Y. \& Ōmura, S. (2007). Microbacterium flavum sp. nov. and Microbacterium lacus sp. nov., isolated from marine environments. Actinomycetologica 21, 53-58.

Kämpfer, P. \& Kroppenstedt, R. M. (1996). Numerical analysis of fatty acid patterns of coryneform bacteria and related taxa. Can J Microbiol 42, 989-1005.

Kumar, S., Tamura, K. \& Nei, M. (2004). MEGA3: Integrated software for Molecular Evolutionary Genetics Analysis and sequence alignment. Brief Bioinform 5, 150-163.

MacKenzie, S. L. (1987). Gas chromatographic analysis of amino acids as the $N$-heptafluorobutyryl isobutyl esters. J Assoc Off Anal Chem 70, 151-160.

Mesbah, M., Premachandran, U. \& Whitman, W. B. (1989). Precise measurement of the $\mathrm{G}+\mathrm{C}$ content of deoxyribonucleic acid by high performance liquid chromatography. Int J Syst Bacteriol 39, 159-167.

Murray, R. G. E., Doetsch, R. N. \& Robinow, F. (1994). Determinative and cytological light microscopy. In Methods for General and Molecular Bacteriology, pp. 21-41. Edited by P. Gerhardt, R. G. E. Murray, W. A. Wood \& N. R. Krieg. Washington, DC: American Society for Microbiology.

Rhuland, L. E., Work, E., Denman, R. F. \& Hoare, D. S. (1955). The behavior of the isomers of $\alpha, \varepsilon$-diaminopimelic acid on paper chromatograms. J Am Chem Soc 77, 4844-4846.

Schleifer, K. H. \& Seidl, P. H. (1985). Chemical composition and structure of murein. In Chemical Methods in Bacterial Systematics, pp. 201-215. Edited by M. Goodfellow \& D. E. Minnikin. London: Academic Press. 
Schumann, P., Prauser, H., Rainey, F. A., Stackebrandt, E. \& Hirsch, P. (1997). Friedmanniella antarctica gen. nov., sp. nov., an LL-diaminopimelic acid-containing actinomycete from Antarctic sandstone. Int J Syst Bacteriol 47, 278-283.

Smibert, R. M. \& Krieg, N. R. (1994). Phenotypic characterization. In Methods for General and Molecular Bacteriology, pp. 611-651. Edited by P. Gerhardt, R. G. E. Murray, W. A. Wood \& N. R. Krieg. Washington, DC: American Society for Microbiology.

Stackebrandt, E. \& Ebers, J. (2006). Taxonomic parameters revisited: tarnished gold standards. Microbiol Today 33, 152-155.

Thompson, J. D., Higgins, D. G. \& Gibson, T. J. (1994). CLUSTAL W: improving the sensitivity of progressive multiple sequence alignment through sequence weighting, position-specific gap penalties and weight matrix choice. Nucleic Acids Res 22, 4673-4680.

Tindall, B. J. (1989). Fully saturated menaquinones in the archaebacterium Pyrobaculum islandicum. FEMS Microbiol Lett 60, 251-254.

Tóth, E. M., Schumann, P., Borsodi, A. K., Kéki, Z., Kovács, A. L. \&

Márialigeti, K. (2008). Wohlfahrtiimonas chitiniclastica gen. nov., sp. nov., a new $\gamma$-proteobacterium isolated from Wohlfahrtia magnifica (Diptera: Sarcophagidae). Int J Syst Evol Microbiol 58, 976-981.

Uchida, K., Kudo, T., Suzuki, K. \& Nakase, T. (1999). A new rapid method of glycolate test by diethyl ether extraction, which is applicable to a small amount of bacterial cells of less than one milligram. J Gen Appl Microbiol 45, 49-56.

Vaz-Moreira, I., Nobre, M. F., Nunes, O. C. \& Manaia, C. M. (2007). Gulbenkiania mobilis gen. nov., sp. nov., isolated from treated municipal wastewater. Int J Syst Evol Microbiol 57, 1108-1112.

Vaz-Moreira, I., Silva, E., Manaia, C. M. \& Nunes, O. C. (2008). Diversity of bacterial isolates from Portuguese commercial and homemade composts. Microb Ecol 55, 714-722.

Wayne, L. G., Brenner, D. J., Colwell, R. R., Grimont, P. A. D., Kandler, O., Krichevsky, M. I., Moore, L. H., Moore, W. E. C., Murray, R. G. E. \& other authors (1987). International Committee on Systematic Bacteriology. Report of the ad hoc committee on reconciliation of approaches to bacterial systematics. Int $J$ Syst Bacteriol 37, 463-464. 